\title{
Investigating the Effect of Dividend Payments on the Economic Value Added of Companies Listed in Tehran Stock Exchange
}

\author{
Fatemeh Zangeneh, Naragh Branch, Islamic Azad University, Naragh, Iran \\ Ali Kiani, South Tehran Branch, Islamic Azad University, Tehran, Iran \\ Ali Sabbaghian, Naragh Branch, Islamic Azad University, Naragh, Iran
}

\begin{abstract}
The stock exchange, as one of the most important and critical economic centers, plays a significant role in sustainable economic development by attracting and properly directing the investment and liquidity of various groups of the society. The purpose of this study is to investigate the effect of dividend payments on the economic value added of companies listed in the Tehran Stock Exchange. In this research, the statistical population includes all 444 accepted companies in the stock exchange. By examining the financial statements, applying the necessary constraints and performing random sampling, 115 qualified companies were finally extracted. The Cochran formula method was used for sampling. In this study, after collecting the necessary information, the dividend and economic value added of the sample companies were calculated. The relationship between the study variables was measured using Pearson correlation coefficient. The tests and analyzes show that there is a positive correlation coefficient between the dividend and the dependent variable of economic value added in the capital market of Iran.
\end{abstract}

Keywords: Dividend, Economic Value Added, Tehran Stock Exchange

\section{Introduction}

With the development and expansion of global trade, taking advantage of opportunities, confronting the bottlenecks and challenges of the economy, and achieving sustainable economic growth has become important and investment growth, production, and directing the liquidity of general public towards productive sectors are among the key elements for realization of these issues. In this regard, the stock exchange, as one of the most important economic centers, plays a critical role in sustainable economic development by attracting and directing the investment and liquidity of various groups of the society. Proper directing of resources in this market depends on the development and timely disclosure of information. Potential investors in companies stock are the main users of information in the stock market. This group usually acquires the information they need through the capital market. The decision of potential investors is essentially related to 
the purchase of shares in the company. Shareholders and investors use a variety of factors to evaluate companies, including earnings per share (EPS) and dividend per share (DPS), whose changes can provide information about current and future corporate performance. There is a large literature on dividend profits and their role of informing in the market as information content of dividends hypothesis and whether managers use dividend profits as signaling tools for future performance of their companies. The information content of dividends hypothesis is interpreted and examined whether dividend payment can provide information about the economic value added of business firms. Often, the interpretations and examinations of the information content of dividend hypothesis have studied whether dividend payment can provide information about the economic value added of business firms. In this research, we will also examine dividend information content on the value added of the companies listed in Tehran Stock Exchange based on the information content of dividend hypothesis.

\section{Previous research}

Rezaei Ahmadabadi et al. (2013) examined the effect of working capital management on performance criteria including refined economic value added and market value added for companies listed in the Tehran Stock Exchange during 2006 and 2010. The results of the hypothesis test indicate that there is no significant relationship between cash conversion cycle and its components and the refined economic value added, but they have a negative and significant correlation with market value added.

Asad khan, Hossein Shah and Rahman (2012) conducted a study on stock returns and EVA in comparison with other variables such as net income and operating cash flows in the capital market of Pakistan. Their results showed that the contribution of operating cash flows is higher than EVA, and there is also a negative relationship between EVA and stock returns.

Charo Andisavat (2011) examined the explanatory power of various accounting metrics (EPS, ROS, ROE, ROA) and value-based metrics (MVA, EVA) to assess the performance of companies in the stock return in Thailand Stock Exchange. He found that the accounting criteria have a higher relation to the stock returns than EVA and MVA.

Asad Khan et al. (2011) conducted an investigation on the relationship between stock returns and economic added value compared to other variables such as net income and operating cash flows in Pakistan's stock market. And the results of this research showed that the share of operational cash flows is higher than EVA, and there is also a negative relationship between EVA and stock returns.

Zayma et al. (2011) studied the relationship between economic value added and market value added and the impact of economics on this relationship in US companies during 2008-2009. The results of their study indicated that there is a positive and significant relationship between economic value added and gross domestic product (as an economic variable) with market value added. 
Ola et al. (2014) conducted a research on the analysis of the relationship between corporate governance and economic value added in Tehran Stock Exchange during the period of 20072010. The results of this study indicate that among five elements of corporate governance (including the ownership percentage of institutional investors, the ownership percentage of major shareholders, the ownership percentage of the controlling shareholders, the separation of the role of CEO from the chairman of the board, and the percentage of non-executive members of the board of directors), only the ownership percentage of institutional investors variable has a significant and positive impact on economic value added. In addition, the causality relation of this variable with the economic value added is also confirmed by the Granger causality test. Iran Khodro, mines and metals investment, and Saipa have the highest impact of corporate governance on economic value added, respectively.

Talebnia and Shoja (2011) conducted a study on the relationship between the ratio of market value added to the accounting profit and the ratio of economic value added to accounting profit in companies listed in Tehran Stock Exchange during the period of 2003-2007. The results showed that there is a weak and positive relationship between MVA/Earning as the dependent variable and EVA/Earning as the independent variable in all companies studied, regardless of their industry.

\section{Methodology}

1. Descriptive statistics of research variables 
Table 1: Descriptive statistics of research variables

\begin{tabular}{|c|c|c|}
\hline & EVA & DPS \\
\hline available & 605 & 446 \\
\hline removed & 85 & 244 \\
\hline average & $2.36 \mathrm{E} 5$ & 240.45 \\
\hline Mean standard error & $4.904 \mathrm{E} 4$ & 11.906 \\
\hline median & $2.98 \mathrm{E} 4$ & 151.00 \\
\hline mode & $-3 . E 5^{\mathrm{a}}$ & 0 \\
\hline Standard deviation & $1.206 \mathrm{E} 6$ & 251.432 \\
\hline variance & $1.455 \mathrm{E} 12$ & $6.322 \mathrm{E} 4$ \\
\hline skewness & 8.431 & .936 \\
\hline Standard error of skewness & .099 & .116 \\
\hline kurtosis & 78.835 & -.090 \\
\hline Standard error of kurtosis & .198 & .231 \\
\hline range & 1.E7 & 990 \\
\hline minimum & -290216 & 0 \\
\hline maximum & 1.E7 & 990 \\
\hline sum & 1.E8 & 107242 \\
\hline
\end{tabular}

a. Multiple modes exist. The smallest value is shown

As can be seen, given that the standard error of skewness and the standard error of kurtosis are between -2 and +2 , the data have near-normal distribution. 
It should be noted that in order to detect outlier observations, a simple regression model is first fitted between independent and dependent variables. Accordingly, by marking the Casewise diagnostics option in SPSS software, outlier observations are marked with a number, therefore, the specified observations are eliminated and the model is fitted again. We continue to do so until the software does not specify any more outlier observation.

\section{-Hypothesis test}

Research hypothesis states that there is a significant relationship between the dividend and economic value added. The statistical expression of this hypothesis is as follows:

$\mathrm{H} 0=$ There is no significant relationship between dividend and economic value added.

$\mathrm{H} 1=$ There is a significant relationship between dividend and economic value added.

$H_{0}: \rho=0$ There is no significant correlation

$H_{1}: \rho \neq 0$ There is a significant correlation

in which $\rho$ is the sign of the population correlation coefficient.

\section{2-1 Correlations Analysis}

Table 2: correlation

\begin{tabular}{|c|c|c|}
\hline & EVA & DPS \\
\hline EVA Pearson Correlation & 1 & $.508^{* *}$ \\
Sig. (2-tailed) & & .000 \\
$\mathrm{~N}$ & 605 & 446 \\
\hline DPS Pearson Correlation & $.508^{* *}$ & 1 \\
Sig. (2-tailed) & .000 & \\
$\mathrm{~N}$ & 446 & 446 \\
\hline
\end{tabular}


Table 2: correlation

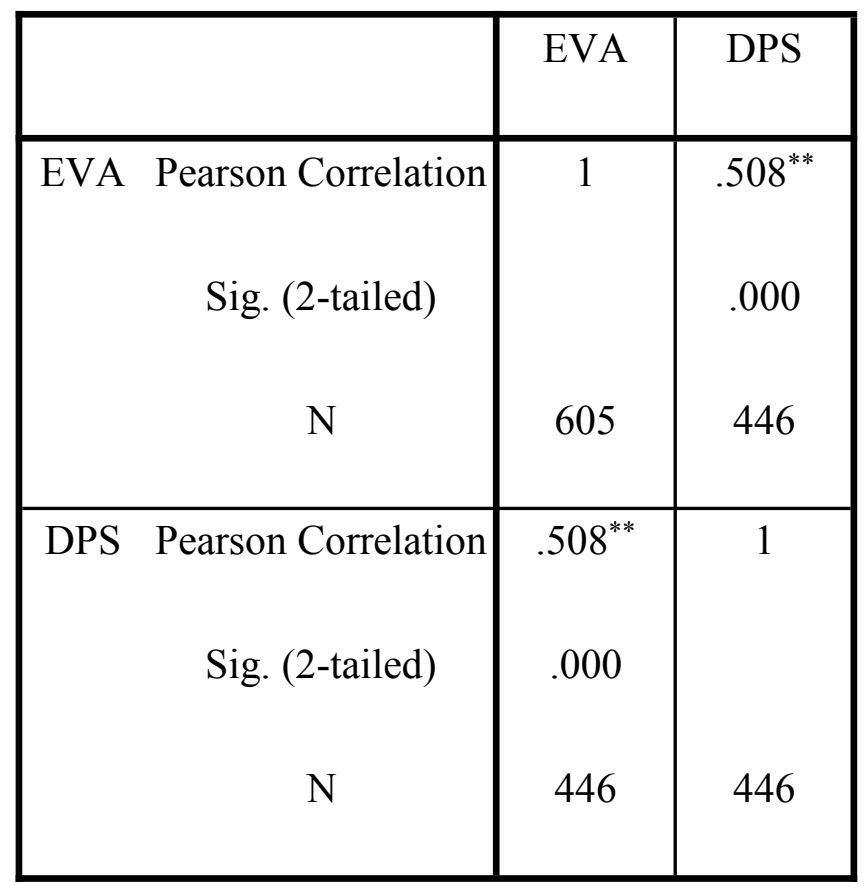

**. Correlation is significant at the 0.01 level (2-

tailed).

According to Table 2, it can be seen that the correlation coefficient between the dividend variable and the dependent variable of economic value added is equal to 0.508 and the probability related to its significance $H_{0}: \rho=0$ is 0.000 , which is smaller than 0.05 , then the assumption $\mathrm{HO}$ is not verified, therefore, with a $95 \%$ probability, a positive and significant relationship is confirmed.

\section{2-2 Analysis of the regression model}

In order to assess the certainty of the existence of a linear relationship between the two variables, the statistical hypotheses of the significance test of the whole regression model is as follows.

H0: There is no linear relationship between the two variables

H1: There is a linear relationship between the two variables

The fitted model for evaluating the hypothesis is as follows:

$y_{t}=\beta_{0}+\beta_{1} X_{t}+\varepsilon_{t}$ 
Table 3: The Output of the Durbin-Watson Test

\begin{tabular}{|c|c|c|c|c|c|}
\hline & & $\begin{array}{c}\text { Coefficien } \\
t \text { of } \\
\text { Model }\end{array}$ & $\begin{array}{c}\text { Adjusted } \\
\text { Correlation } \\
\text { coefficient }\end{array}$ & $\begin{array}{c}\text { The standard } \\
\text { tion } \\
\text { error of the } \\
\text { estimate }\end{array}$ & Durbin-Watson \\
\hline 1 & $.508^{\mathrm{a}}$ & .258 & .256 & 55022.551 & 2.034 \\
\hline
\end{tabular}

a. Predictors: (Constant), DPS

b. Dependent Variable: EVA

Table 4: ANOVA

\begin{tabular}{|c|c|c|c|c|c|}
\hline Model & $\begin{array}{l}\text { Sum of } \\
\text { squares }\end{array}$ & $\begin{array}{l}\text { Degrees } \\
\text { of } \\
\text { freedom }\end{array}$ & $\begin{array}{c}\text { Average } \\
\text { squares }\end{array}$ & $\mathrm{F}$ & $\begin{array}{l}\text { Probabilit } \\
\text { y Statistic }\end{array}$ \\
\hline Regression & $4.668 \mathrm{E} 11$ & 1 & $4.668 \mathrm{E} 11$ & 154.195 & $.000^{\mathrm{a}}$ \\
\hline Residual & $1.344 \mathrm{E} 12$ & 444 & $3.027 \mathrm{E} 9$ & & \\
\hline Total & $1.811 \mathrm{E} 12$ & 445 & & & \\
\hline
\end{tabular}

a. Predictors: (Constant), DPS

b. Dependent Variable: EVA

According to table 3 , it is seen that the adjusted coefficient of determination ( $\mathrm{r} 2$ ) is equal to 0.256 , which means that about $25.6 \%$ of the variations of the response variable (economic value added) can be described by the independent variable (dividend). The probability associated with the zero hypothesis that suggests that there is no linear relationship between the independent variable and the response variable (H0) in Table 4 is equal to 0.000 , which is smaller than 0.05 , therefore, with 95\% confidence, the statistical hypothesis $\mathrm{H} 0$ is not verified. As a result, a significant linear relationship between the two variables is observed, and thus the hypothesis one (H1) is confirmed. 
Table 5: Coefficients

\begin{tabular}{|c|c|c|c|c|c|}
\hline \multirow{2}{*}{ Model } & \multicolumn{2}{|c|}{$\begin{array}{c}\text { Not standardized } \\
\text { coefficients }\end{array}$} & $\begin{array}{c}\text { standardized } \\
\text { coefficients }\end{array}$ & & \\
\cline { 2 - 4 } & B & Std. Error & Beta & \multirow{2}{*}{$\mathrm{t}$} & y statistic \\
\hline 1 (Constant) & -4322.104 & 3606.967 & & -1.198 & .231 \\
& 128.818 & 10.374 & .508 & 12.418 & .000 \\
\hline DPS & & & & & \\
\hline
\end{tabular}

a. Dependent Variable: EVA

According to Table 5, it can be seen that in the standardized coefficients column, the independent variable coefficient is equal to 0.508 , which means that each increment unit in the independent variable leads to an increase of 50.8 units in the response variable. Also, according to Table 5, it is noted that the probability value ( $\mathrm{sig}$ ) of the constant value of the regression model is equal to 0.231 , which is greater than 0.05 , thus the constant value is not significant at $95 \%$ level, and the probability value (sig) of the independent variable coefficient is 0.000 , thus it is significant at $95 \%$ level.

Finally, the fitted model is presented as follows:

$$
E V A=-4322.104+0.508 D P S
$$

2-3 Investigating linear regression assumptions of the research hypothesis

A. The value of the Durbin Watson test statistic is 2.034 , which is in the range of 1.5 to 2.5 , so the assumption of non-correlation between the errors is accepted.

B. In the remainder statistics section of the output, the minimum and maximum of standardized residuals are between -3 and 3 , so in this model, the problem of the existence of outliers is not observed.

C. There was no trend observed in the distribution chart of the standardized residuals in terms of the standardized predictions and the symmetry of the observations is around zero, thus the homogeneity of the residuals variance can be confirmed.

E. By comparing the frequency distribution of errors diagram and the normal distribution diagram, it can be observed that the distribution of errors is almost normal, so that regression can be used. Also, the mean value presented on the right side of the graph is very small (close to zero) and the standard deviation is close to one, thus the residuals have a normal distribution. 
Regarding the single variable regression model, to estimate the best regression, regression analysis of curve estimation was performed. According to the following table, it can be observed that the relationship between linear regression and the second and third degree regression is significant, and based on the F statistic, it can be noted that linear regression has the highest value of $\mathrm{F}$, therefore, it is the best regression estimate.

\section{Table 6: Model Summary and Parameter Estimates}

\section{Dependent}

Variable:EVA

\begin{tabular}{|c|c|c|c|c|c|c|c|c|c|}
\hline \multirow[b]{2}{*}{ Equation } & \multicolumn{5}{|c|}{ Model Summary } & \multicolumn{4}{|c|}{ Parameter Estimates } \\
\hline & R Square & $F$ & $d f 1$ & $d f 2$ & Sig. & Constant & b1 & $b 2$ & b3 \\
\hline $\begin{array}{l}\text { Linear } \\
\text { Logarithmic } \\
{ }_{a}\end{array}$ & .258 & 154.195 & 1 & 444 & .000 & $-4.322 E 3$ & 128.818 & & \\
\hline Inverse ${ }^{b}$ & & . & & . & & & . & & \\
\hline Quadratic & .262 & 78.740 & 2 & 443 & .000 & $-7.734 E 3$ & 176.593 & -.067 & \\
\hline Cubic & .265 & 53.062 & 3 & 442 & .000 & $-5.596 E 3$ & 103.898 & .188 & .000 \\
\hline Powera & . & . & & . & . & .000 & .000 & & \\
\hline
\end{tabular}

The independent variable is DPS.

a. The independent variable (DPS) contains non-positive values. The minimum value is 0 . The Logarithmic and Power models cannot be calculated.

b. The independent variable (DPS) contains values of zero. The Inverse and S models cannot be calculated. 


\section{Figure1:Distribution chart}

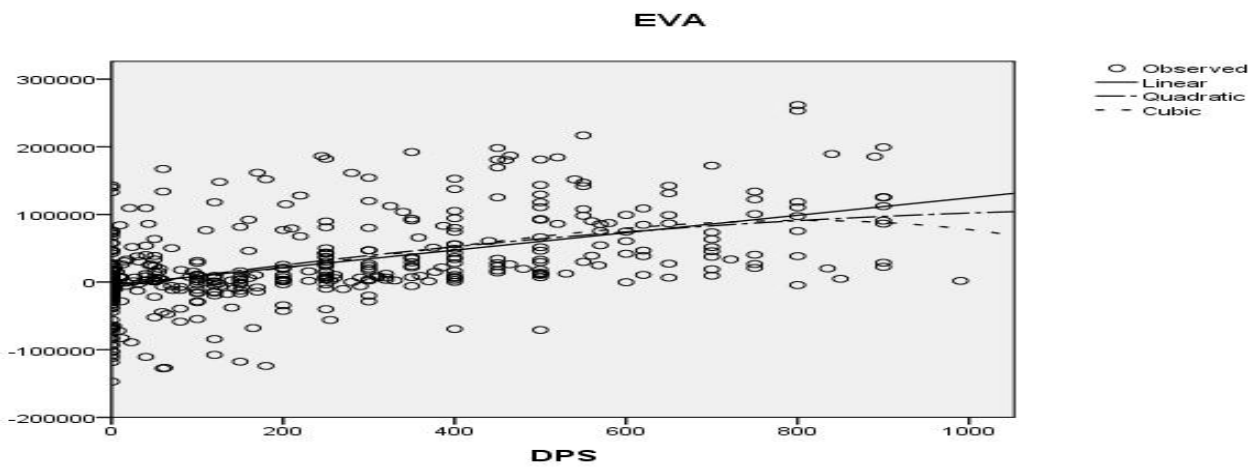

\section{Conclusion}

In this research, after collecting the necessary information and data, the dividend and economic value added of the sample companies were calculated, the relationship between the research variables has been measured using Pearson correlation coefficient and then the $\mathrm{T}$ test with $\mathrm{df}=\mathrm{n}$ 2 degree of freedom and $95 \%$ confidence level was used to determine the significance of the correlation between the abovementioned criteria.

\section{The Hypothesis Test Results and Their Analysis}

The first hypothesis states that there is a significant relationship between dividend and economic value added:

According to the tests and analyses carried out by regression and correlation in Chapter 4, we concluded that there is a positive correlation coefficient between the dividend and the dependent variable of economic value added in the capital market of Iran, which is equal to 0.508 . This correlation coefficient is approximately moderate, and in fact the above variables cannot act independently. According to the adjusted coefficient of determination, which is 0.256 , it is shown that $25.6 \%$ of the variations of the response variable (economic value added) is obtained by the independent variable (dividend), and the rest is related to the variables that are not considered in this study. The research has shown that the above hypothesis is confirmed, and there is a linear positive relationship between dividend and economic value added. The probability value of the zero hypothesis, which is based on the absence of a linear relationship between the independent variable and the response variable $(\mathrm{H} 0)$, is 0.000 , which is smaller than 0.05 , therefore, with $95 \%$ confidence, this statistical hypothesis is not verified. As a result, a significant linear relationship between the two variables is observed, and thus the hypothesis one (H1) is confirmed. 


\section{References}

Anvari Rostami, Ali Asghar, Tehrani, Reza, Seraji, Hasan, (2010), Investigation of the relationship between economic value added, earnings before interest and taxes, and cash flow of operational activities with the stock market value of listed companies in Tehran Stock Exchange, Journal of the Accounting and Auditing Review, No. 37, pp. 3-21

Jahankhani, Ali and Sohrabi, Jamshid, (2009). The role of refined economic value added in increasing shareholder wealth, Quarterly Journal of the Stock Exchange (Year: 2, Issue: 5, pp. 129-169).

Rahnamay Rud poshti, Fereydoun, Jalili, Mohammad; Scientific Foundations and Modern Methods of Calculating Economic Value Added (EVA) and its Application for Evaluation of Financial Performance and Capital Management in Tehran Stock Exchange, Strategic Management Research Quarterly, Summer and Autumn 2008 - No. 40, pp. 31-50.

Sharifi Ghotb Abadi, Mehdi (2007), Comparative study on the impact of the information content and load of economic value added and cash obtained from operations in predicting future profits in companies listed in Tehran Stock Exchange, Master's thesis, Shahid Beheshti University, Faculty of Management And accounting.

Naderi Bani, Rahmatullah (2007), An Investigation of Incremental Information Content of Profit and Cash Flows from Operations with Stock Returns, Master's Thesis, Shahid Beheshti University, Faculty of Management and Accounting.

Zaima ,P.M. \& Palepu, K.G. (2011) . "The effect of firms' financial disclosure policies Accounting and economics, Vol.22, PP.249-281.

Dut, In-Mu. Qi, Daqing, Wu, woody.(2010) . The nature of information in accruals and cash flows in an emerging capital market: The case of China", The international journal of accounting, Vol.36, P.P.391-406.

LaFond, R. \& Watts, R. (2008) . "The Information Role of Conservatism", The Accounting Review, Vol. 83, PP.447-4.

Ramana, M.S. (2005). "Information Asymmetries and the Value Relevance of Vol. 8, No.2, PP.64-75.

Warr,R.S.(2005). "A Empirical study oF Inflation distortions to EVA", Journal oF Economics and Business 57, 119-137. 